\title{
Rented vs. Owner-Occupied Housing and Monetary Policy
}

\author{
Margarita Rubio* \\ University of Nottingham
}

September 2017

\begin{abstract}
The aim of this paper is to show how housing tenure (rented vs. owner-occupied) affects monetary policy. I propose a dynamic stochastic general equilibrium model with housing, both owned and rented. First, I analyze how, in the model, preference parameters, fiscal incentives, and institutional factors determine the rental market share and the residential debt-to-GDP ratio. Then, within this framework, I study how the transmission and optimality of monetary policy differ depending on these factors. From a positive perspective, impulse responses illustrate differences in the monetary transmission mechanism. I find that of all factors, tax incentives generate the largest differences. In normative terms, results show that when the relative size of the rental market is larger, monetary policy is more stabilizing. An optimal monetary policy analysis also suggests that in this case, monetary policy should respond more aggressively to inflation and disregard output, because the financial accelerator effects are weaker.
\end{abstract}

Keywords: Housing market, rental, owner-occupied housing, monetary policy

JEL: E21, E3, E51, E6

\footnotetext{
${ }^{*}$ The author would like to thank seminar participants at the University of Nottingham, the National Bank of Poland, Michal Rubaszek, and Jose A. Carrasco-Gallego for their very useful comments. This paper was presented at the National Bank of Poland Conference, "The Monetary Transmission Mechanism in Diverse Economies," 2013, the CGBCR Conference at the University of Manchester, the MMF, the XXII Encuentro de Economía Pública, SNDE 2015, and the 11th Dynare Conference. Special thanks to José E. Boscá for serving as a discussant and giving excellent comments. Part of this project was undertaken when the author was visiting the National Bank of Poland. She would like to thank them for their hospitality. All errors are mine.
} 


\section{Introduction}

Housing market structure shows remarkable cross-country differences. In particular, these divergences are especially important in terms of the relative weight, efficiency, and dynamics of the rental sector. The proportion of households that rent ranges from less than $10 \%$ in some Eastern European countries, to more than $50 \%$ in Switzerland, Japan, and Germany (see Figure A1 in the Appendix). Within the European Union, Germany and Spain are notable for having the highest and lowest rental ratios, respectively. For example, in 2008, while the rental share in Europe was $33.2 \%$ on average, it was $15.5 \%$ in Spain and $56.8 \%$ in Germany.

This heterogeneity, which may be due to several factors, including cultural preferences, taxation, development of the rental market, demographics, and institutional efficiency, among others, can have a significant effect on the transmission of different economic shocks and on the conduct of monetary policy. Therefore, it is a relevant topic of study.

First, the relative weight of the rental market can be a consequence of different household preferences or cultural factors. For example, in southern Europe, children tend to live with their parents for a longer period and, therefore, enter the residential property market relatively late. Furthermore, they are frequently financially supported by their parents, and even receive their property from them [see Earley (2004)]. There are also cultural attitudes to property that have an impact on the relative importance of the different forms of housing tenure. For example, for some consumers, owner-occupation is a symbol of social status or it implies the possibility of bequests that can be a life objective by itself. Differences in the prevalence of these motives contribute to explaining the divergences in cross-country housing tenure regimes.

Institutional factors around the housing market represent another important source of heterogeneity across countries in terms of the relative size of the rental market. Apart from specific market regulation, the functioning of the legal system has a direct effect on its efficiency [Mora-Sanguinetti (2011) offers a detailed analysis of these elements for different European countries]. Given the evidence of cross-country

differences in the capacity of the legal system to enforce contracts, Casas-Arce and Saiz (2010) analyze this topic with an international sample and estimate that the less efficient the legal system, the lower is the rental market share in the economy. Figure A2 and Table A1 in the Appendix show that legal system differences across countries could affect the efficiency and functioning of rental markets, and ultimately their size. 
On the other hand, tax incentives for owner-occupied home purchase reduce the proportion of rental housing. In the same way, fiscal deductions associated with mortgage interest payments also increase home purchases. Fiscal incentives to the rental sector would increase the relative size of this market. Figure A3 in the Appendix shows some differences in taxation across countries. In the majority of the OECD countries, governments have tended to give incentives to home purchases, through favorable tax treatment of owner-occupied housing. This policy orientation-mainly through fiscal benefits to home purchasers - has been common in many countries. However, there have recently been some other initiatives to promote rental housing, given that an underdeveloped rental sector has been considered to be harmful to the economy.

It is also remarkable that housing is treated as a mechanism to generate wealth. In many countries, access to credit markets requires a housing collateral and it implies a mortgage equity withdrawal. In those countries in which this practice exists, owning a house has an additional benefit that can positively affect the propensity of households to purchase houses. The size of the rental market then has implications for the size of financial accelerator effects and for the transmission of monetary policy. These financial accelerator effects will depend on the relative proportion of owners and renters. Therefore, at the macroeconomic level, these effects may be larger the greater is the importance of property in the economy, because the macroeconomy will be more sensitive to changes in house prices. In other words, the financial accelerator caused by collateral effects will be stronger in this case and monetary policy will potentially have larger effects on the economy.

This paper is related to the literature concerning cross-country differences with respect to housing tenure. In particular, there are three types of studies. On the one hand, there are papers that compare rental market characteristics in different countries and obtain conclusions about the importance of these features for the relative incidence of owners and renters [Pomeroy and Godbout (2011), Earley (2004), among others]. A second group of studies analyses the relationship between housing tenure regime and different economic variables, using microeconometric techniques with panel or cross-section data for different countries, especially the OECD [see, for example, Andrews and Caldera (2011) or Casas-Arce and Saiz (2010)]. Finally, there are also studies that analyze the macroeconomic implications of the rental market relative size in a general equilibrium context [see, for example, Ortega et al. (2011) and Mora-Sanguinetti and Rubio (2014), for the Spanish economy]. ${ }^{1}$ This paper is closest to the latter set

\footnotetext{
${ }^{1}$ Alpanda and Zubairy (2013) also consider a DSGE model with rental market to study the effects of tax policy on the macroeconomy, albeit abstracting from monetary policy.
} 
of studies.

The contribution of this paper is that I study how differences in housing tenure affect monetary policy, something novel in the literature. I propose a general equilibrium model that is able to capture these differences in housing tenure across countries. The modeling strategy and its calibration aims at providing a general framework to study these issues, without having any specific economy in mind. Financial accelerator effects of owner-occupied housing are taken into account through the introduction of collateral constraints on borrowers. Cultural, institutional and preference factors are included in the utility function of agents. Housing-related taxation appears explicitly through home purchase and rental subsidies. Through model simulations, I analyze how all these factors affect the steady-state values of relevant variables such as residential debt and rental market relative proportion. Then, I study how these features affect the monetary policy transmission mechanism by showing the dynamics of the model under different scenarios. Finally, from a normative perspective, I show how all these structural and fiscal factors in the housing markets affect the efficiency and optimal conduct of monetary policy.

Results show that all these factors are able to affect the steady-state proportion of rentals versus owner-occupied housing, as well as the residential debt-to-GDP ratio. However, in terms of the dynamics of the model, taxation is the most significant feature affecting the monetary policy transmission mechanism. From a normative perspective, a relatively large rental market makes monetary policy more stabilizing. However, when the government subsidizes home purchasers, the link between monetary policy and house prices is weakened and this creates an even more stable scenario. In terms of optimal monetary policy, when the rental market is relatively large, monetary policy should respond more aggressively to inflation and disregard output, because the financial accelerator effects are weaker in this case.

The paper proceeds as follows. Section 2 presents the theoretical model. Section 3 simulates the model and shows how the steady-state values of debt and rental size are affected when preferences, taxation, and efficiency vary. Section 4 displays the dynamics of the model through impulse responses. Section 5 computes policy efficiency frontiers. Section 6 discusses optimal monetary policy. Section 7 concludes. 


\section{The Model}

Iacoviello (2005) proposed a way to introduce housing markets in a dynamic stochastic general equilibrium model, which is suitable to study the transmission of monetary policy through the housing market and analyze welfare. In Iacoviello-type models, there are two types of agents, savers and borrowers. These consumers differ in their discount factors and in the fact that borrowers have collateral constraints in order to have access to credit markets. In particular, savers are more patient than borrowers and the latter need housing collateral to borrow. In this paper, I extend the Iacoviello (2005) framework to include rental markets to evaluate the implications of housing tenure on monetary policy. ${ }^{2}$

\subsection{Consumers}

\subsubsection{Savers}

Savers maximize their utility function by choosing consumption, housing services, ${ }^{3}$ and working hours. Note that the difference between this utility function and the standard one is that housing enters the utility function as an argument:

$$
\max E_{0} \sum_{t=0}^{\infty} \beta_{s}^{t}\left(\log C_{s, t}+j \log H_{s, t}-\frac{\left(N_{s, t}\right)^{\eta}}{\eta}\right),
$$

where $\beta_{s} \in(0,1)$ is the patient discount factor, $E_{0}$ is the expectation operator, and $C_{s, t}, H_{s, t}$, and $N_{s, t}$ represent consumption at time t, the housing stock, and working hours, respectively. $1 /(\eta-1)$ is the labor supply elasticity, $\eta>0$, and $j>0$ constitutes the relative weight of housing in the utility function.

The budget constraint is:

$$
\begin{gathered}
C_{s, t}+b_{s, t}+q_{h, t}\left[\left(1-\tau_{h}\right)\left(H_{s, t}-H_{s, t-1}\right)+\left(H_{z, t}-H_{z, t-1}\right)\right] \leq \frac{R_{t-1} b_{s, t-1}}{\pi_{t}} \\
+w_{s, t} N_{s, t}+q_{z, t} H_{z, t}+S_{t}-T_{t}
\end{gathered}
$$

where $q_{h, t}$ is the real housing price and $w_{s, t}$ is the savers' real wage. These agents can purchase or sell housing at the current price $q_{h, t}$, either to live in the house $\left(H_{s, t}\right)$, or to rent it $\left(H_{z, t}\right)$. Savers obtain $q_{z, t}$ for rentals. There exists a subsidy $\tau_{h}$ to home purchasers. As it will be shown, this group of agents will

\footnotetext{
${ }^{2}$ The advantage of following this approach is that this model is comparable with the literature on housing and the financial accelerator, thus making it easier to interpret the results.

${ }^{3}$ It is assumed that housing services are proportional to housing stock.
} 
choose not to borrow at all, because they are the savers in the economy. Savings are given by $b_{s, t}$, at the interest rate $R_{t-1} \cdot \pi_{t}$ is the inflation rate at period t. $S_{t}$ are the profits that firms receive. $T_{t}$ is a lump-sum government tax.

The first-order conditions for this optimization problem are as follows.

$$
\begin{gathered}
\frac{1}{C_{s, t}}=\beta_{s} E_{t}\left(\frac{R_{t}}{C_{s, t+1} \pi_{t+1}}\right) \\
\frac{j}{H_{s, t}}=\left(1-\tau_{h}\right)\left[\frac{q_{h, t}}{C_{s, t}}-\beta_{s} E_{t}\left(\frac{q_{t+1}}{C_{s, t+1}}\right)\right] \\
w_{s, t}=\left(N_{s, t}\right)^{\eta}-1 C_{s, t} \\
\frac{q_{h, t}}{C_{s, t}}=\frac{q_{z, t}}{C_{s, t}}+\beta_{s} E_{t} \frac{q_{h, t+1}}{C_{s, t+1}}
\end{gathered}
$$

Equation (2) is the Euler equation, the intertemporal condition for consumption. Equation (3) represents the intertemporal condition for housing, in which, at the margin, benefits for consuming housing equate costs in terms of consumption. Equation (4) is the labor-supply condition. Equation (5) is the first-order condition for housing that is purchased to rent.

\subsubsection{Borrowers}

Borrowers solve the following problem:

$$
\max E_{0} \sum_{t=0}^{\infty} \beta_{b}^{t}\left(\log C_{b, t}+j \log \widetilde{H}_{b, t}-\frac{\left(N_{b, t}\right)^{\eta}}{\eta}\right)
$$

where $\beta_{b} \in(0,1)$ is the impatient agents' discount factor. $\tilde{H}_{b, t}$ is a composite of owner-occupied housing and rental services, represented by a CES aggregator. $\omega_{h}$ indicates the preference for owner-occupied housing and $\varepsilon_{h}$ is the elasticity of substitution between preferences for owner-occupied housing and rental. In this way, borrowers derive utility from the two types of housing. Note that this does not literally mean that each borrower lives simultaneously in their own house and in a rented house. Instead, the interpretation is that there exists a large representative borrower-type household with a continuum of members, some of whom live in owner-occupied houses, the rest of whom live in rented houses. This composite index in the equation thus represents the aggregate preferences of all household members with 
respect to each kind of housing service: ${ }^{4}$

$$
\tilde{H}_{b, t}=\left[\omega_{h}^{1 / \varepsilon_{h}}\left(H_{b, t}\right)^{\left(\varepsilon_{h}-1\right) / \varepsilon_{h}}+\left(1-\omega_{h}\right)^{1 / \varepsilon_{h}}\left(H_{z, t}\right)^{\left(\varepsilon_{h}-1\right) / \varepsilon_{h}}\right]^{\varepsilon_{h} /\left(\varepsilon_{h}-1\right)},
$$

where $H_{b, t}$ is the owner-occupied borrowers' housing stock and $H_{z, t}$ are rental services. Subject to the budget constraint and the collateral constraint:

$$
\begin{gathered}
C_{b, t}+\frac{R_{t-1} b_{b, t-1}}{\pi_{t}}+q_{h, t}\left(1-\tau_{h}\right)\left(H_{b, t}-H_{b, t-1}\right)+q_{z, t}\left(1-\tau_{z}\right) H_{z, t}=b_{b, t}+w_{b, t} N_{b, t}, \\
b_{b, t} \leq E_{t}\left(\frac{1}{R_{t}} k q_{t+1} H_{b, t} \pi_{t+1}\right),
\end{gathered}
$$

where $b_{b, t}$ represents borrowings. $k$ can be interpreted as a loan-to-value ratio. The collateral constraints limit borrowings to the discounted present value of the borrowers' owner-occupied housing. Note that this constraint creates a financial accelerator effect because loans depend directly on housing values. The first-order conditions of this maximization problem are as follows:

$$
\begin{gathered}
\frac{1}{C_{b, t}}=\beta_{b} E_{t}\left(\frac{R_{t}}{C_{b, t+1} \pi_{t+1}}\right)+\lambda_{t} \\
\frac{j}{\tilde{H}_{b, t}}\left(\frac{\omega_{h} \tilde{H}_{b, t}}{H_{b, t}}\right)^{1 / \varepsilon_{h}}=\left(1-\tau_{h}\right)\left(\frac{q_{h, t}}{C_{b, t}}-\beta_{b} E_{t} \frac{q_{h, t+1}}{C_{b, t+1}}\right)-\lambda_{t} k E_{t} q_{h, t+1} \frac{\pi_{t+1}}{R_{t}}, \\
w_{b, t}=\left(N_{b, t}\right)^{\eta}-1 C_{b, t}, \\
\frac{j}{\tilde{H}_{b, t}}\left(\frac{\left(1-\omega_{h}\right) \tilde{H}_{b, t}}{H_{z, t}}\right)^{1 / \varepsilon_{h}}=\left(1-\tau_{z}\right) \frac{q_{z, t}}{C_{b, t}}
\end{gathered}
$$

where $\lambda_{t}$ is the Lagrange multiplier of the collateral constraint. ${ }^{5}$ These first-order conditions can be interpreted analogously to those of savers. However, an important difference lies in housing demand, equation (10). It equates the marginal utility of owner-occupied housing to the effective user cost of

\footnotetext{
${ }^{4}$ In this way, the model is comparable to other Iacoviello-type models in which housing is indivisible and is represented by a continuum consumed by a representative agent. There are other studies that treat nonconvexities in housing using non-linear computational techniques [see, for example, Chambers et al. (2009), Nakajima (2010), Chatterjee and Eyigungor (2014), Corbae and Quintin (forthcoming)]. However, in this paper, I follow the Iacoviello-type approach.

${ }^{5}$ Through simple algebra it can be shown that the Lagrange multiplier is positive in the steady state and thus the collateral constraint holds with equality.
} 
housing minus the marginal value of housing as collateral. Therefore, ceteris paribus, an increase in the value of the collateral has a positive effect on the owner-occupied housing demand of borrowers.

\section{$2.2 \quad$ Firms}

\subsubsection{Intermediate Goods Producers}

The intermediate goods market is perfectly competitive. The homogeneous intermediate good is produced according to the following technology:

$$
Y_{t}=N_{s, t}^{\gamma} N_{b, t}^{(1-\gamma)}
$$

where $N_{s, t}$ and $N_{b, t}$ represent the savers' and borrowers' labor supply, respectively. ${ }^{6} \gamma$ represents the labor-income ratio of patient agents. Free entry to the sector implies a zero-profit condition, which implies the following labor demand for both agents:

$$
\begin{gathered}
w_{s, t}=\frac{1}{X_{t}} \gamma \frac{Y_{t}}{N_{s, t}}, \\
w_{b, t}=\frac{1}{X_{t}}(1-\gamma) \frac{Y_{t}}{N_{b, t}},
\end{gathered}
$$

where $X_{t}$ is the markup or the inverse of the marginal cost. ${ }^{7}$

\subsubsection{Final Goods Producers}

A continuum of monopolistically competitive firms produce final goods. Prices are set following the Calvo (1983) mechanism. ${ }^{8}$ This implies the following log-linear approximation of the new Keynesian Phillips curve for inflation:

$$
\log \pi_{t}=\beta_{s} E_{t} \log \pi_{t+1}+\frac{(1-\theta)\left(1-\theta \beta^{s}\right)}{\theta} \log X_{t}
$$

where $\theta$ is the probability that firms do not change prices.

\footnotetext{
${ }^{6}$ By symmetry, I omit the indices corresponding to each intermediate good.

${ }^{7}$ The complete derivation of this problem is available upon request.

${ }^{8}$ Note that the model does not include any price rigidities in the housing market, as most models of this kind. However, it needs to be said that Barsky et al. (2007) find that sticky durable prices may have implications for shock transmission. On the contrary, Jeske and Liu (2013) find that, although empirically rental prices tend to be sticky, they are not an important component of optimal monetary policy.
} 


\subsection{Monetary Authority}

The central bank sets interest rates according to a Taylor rule:

$$
R_{t}=\left(R_{t-1}\right)^{\rho}\left[\pi_{t}^{\left(1+\phi_{\pi}\right)}\left(\frac{Y_{t}}{Y_{t-1}}\right)^{\phi_{y}} R\right]^{(1-\rho)} \varepsilon_{R, t}
$$

where $0 \leq \rho \leq 1$ is the parameter associated with interest rate smoothing. $\phi_{\pi}>0, \phi_{y}>0$ measure the interest rate response to inflation and output, respectively. $R$ is the steady-state value of the interest rate. $\varepsilon_{R, t}$ is a white noise shock with 0 average and $\sigma_{\varepsilon}^{2}$ variance. $^{9}$

\subsection{Equilibrium Conditions}

The equilibrium condition for the goods markets is:

$$
Y_{t}=C_{s, t}+C_{b, t}
$$

Housing supply is fixed and normalized to unity:

$$
H_{s, t}+H_{b, t}+H_{z, t}=1
$$

The equilibrium government budget constraint is given by:

$$
T_{t}=\tau_{z} q_{t}^{z} H_{z, t}+\tau_{h} q_{t}^{h}\left[\left(H_{s, t}-H_{s, t-1}\right)+\left(H_{b, t}-H_{b, t-1}\right)\right] .
$$

\section{Simulation}

\subsection{Parameter Values for Benchmark}

Table 1 presents a summary of the simulation parameter values.

\footnotetext{
${ }^{9}$ In this model, the inflation rate that feeds into the Taylor rule does not take into account the rental rate of housing. Jeske and Liu (2013) explore this issue in a DSGE model and find that the optimal weight on rental inflation in the Taylor rule is small.
} 


\begin{tabular}{lll}
\hline Table 1: Parameter values \\
\hline \hline$\beta_{s}$ & 0.99 & Savers' discount factor \\
$\beta_{b}$ & 0.98 & Borrowers' discount factor \\
$j$ & 0.1 & Housing weight in the utility function \\
$\eta-1$ & 1 & Inverse of the labor-supply elasticity \\
$k$ & 0.8 & Loan-to-value ratio \\
$\gamma$ & 0.64 & Savers' labor-income share \\
$X$ & 1.2 & Steady-state markup \\
$\theta$ & 0.75 & Probability of not changing prices \\
$\varepsilon_{h}$ & 2 & Elasticity of substitution between owner-occupied and rental \\
$\omega_{h}$ & 0.5 & Preference for owner-occupied housing \\
$\tau_{h}$ & 0.10 & Subsidy to house purchases \\
$\tau_{z}$ & 0 & Subsidy to rentals \\
$\rho$ & 0.8 & Interest rate smoothing \\
$\phi_{\pi}$ & 0.5 & Inflation coefficient TR \\
$\phi_{y}$ & 0 & Output coefficient TR \\
\hline
\end{tabular}

The model is calibrated for the US economy. The discount factor for savers, $\beta_{s}$, is set to 0.99 corresponding to an annualized interest rate of $4 \%$ in the steady state. The discount factor for borrowers is set to $0.98 .{ }^{10}$ The weight of housing in the utility function, $j$, is set to 0.1 , which implies a GDP-tohousing wealth ratio of approximately 1.40 in the steady state, consistent with US data. ${ }^{11}$ The parameter $\eta$ takes the value of 2 , implying a labor-supply elasticity of $1 .{ }^{12}$ Concerning the value that proxies the loan-to-value ratio, $k$, is set to 0.8 , an average for the US and Europe data. To set the value of the labor-income share of savers to 0.64, I follow Iacoviello (2005) estimates. The steady-state markup takes the value of 1.2 . The probability of firms not changing prices is fixed to 0.75 , which implies that prices change on average every four quarters. The value for $\varepsilon_{h}$ is set to 2, following Ortega et al. (2011). For the Taylor rule parameters, I use $\rho=0.8$ and $\phi_{\pi}=0.5$, the first implying a realistic degree of

\footnotetext{
${ }^{10}$ Lawrance (1991) estimates discount factors for low-income consumers at between 0.95 and 0.98 at a quarterly frequency. I take the most conservative value.

${ }^{11}$ The parameter j mainly controls the stock of residential housing over annual output, which is 140 percent, in line with data from the Flow of Funds accounts (See Table B.100 from the US Flow of Funds data). In this model, consumption is the only component of GDP. To make the ratio comparable with the data I multiply it by 0.6 , which is approximately what nondurable consumption and services account for in the GDP, according to the data in the NIPA tables.

${ }^{12}$ Microeconomic estimations suggest values in the range of 0 and 0.5 (for males). Domeij and Flodén (2006) find that, in the presence of credit constraints, these estimated values have a $50 \%$ downward bias.
} 
interest rate smoothing and the second consistent with the initial value proposed by Taylor in 1993. I set subsidies to purchase and rent to values corresponding to the US economy. In particular, I set $\tau_{h}$ to $10 \%$ to approximate the 10 percent tax credit of the purchase price of a principal residence that was introduced in the US after the crisis. ${ }^{13}$ For $\omega_{h}$, the preference parameter referring to owning versus renting, I calibrate it to 0.32 to match the residential debt to GDP ratio and the size of the rental market in the US, around $70 \%$ in the post-crisis period and $37 \%$, respectively. ${ }^{14}$

\subsection{Factors That Influence the Relative Proportion of Home Purchases versus Rentals}

In this section, I analyze how the values of the key parameters that determine housing tenure affect the steady-state proportion of rentals with respect to property housing ${ }^{15}$ as well as the residential debt-toGDP ratio. In particular, I consider the relative preference of owner-occupied housing versus rental, and the fiscal treatment of housing, i.e. subsidies to home purchases or rentals.

As stated in the Introduction, the different relative weight of rental markets could in part be caused by differences in household preferences or cultural factors. Then, we could think that German households simply prefer to rent while Spanish households have developed a preference toward purchasing, which could be the consequence of cultural factors. In the model that has been presented, this factor would be included in the parameter $\omega_{h}$, which represents the preference for owner-occupied housing in the utility function. In Table 2, I present the steady states for some representative values of this parameter, including the US benchmark, for comparison (in bold).

\begin{tabular}{lccccc}
\hline \hline Table 2: Steady-state values for different $\omega_{h}$ & & \\
\hline & $\omega_{h}=0.2$ & $\omega_{h}=\mathbf{0 . 3 2}$ & $\omega_{h}=0.5$ & $\omega_{h}=0.8$ & $\omega_{h}=0.9$ \\
Debt/GDP & 0.43 & $\mathbf{0 . 6 9}$ & 1.08 & 1.75 & 1.97 \\
Rental/Purchase & 0.40 & $\mathbf{0 . 3 6}$ & 0.29 & 0.20 & 0.17 \\
\hline \hline
\end{tabular}

As expected, the model generates a situation in which the higher is the weight of owner-occupied housing relative to rentals in the borrowers utility function, the larger is the debt ratio in the economy and the lower is the proportion renting relative to home purchase. The parameter $\omega_{h}$ reflects how preferences affect the relative weight of the rental sector across countries. Low values of this parameter

\footnotetext{
${ }^{13}$ See Dynan et al. (2013) for further details.

${ }^{14}$ Data can be found in the European Mortgage Federation (EMF) and the National Multifamily Housing Council (NMHC).

${ }^{15}$ This ratio has been calculated as $\mathrm{Hz} / \mathrm{H}$.
} 
imply that owner-occupied housing has less weight in the utility function for borrowers; thus, the model generates a low residential debt-to-GDP ratio, because agents do not as frequently borrow to purchase housing, they prefer to substitute purchase with rentals. As a consequence, the proportion of rentals relative to purchases is larger. This parameter has a powerful effect on the rental share in the market, however, alone, it cannot explain the whole cross-country differences. For instance, an extremely low proportion of rentals in a country like Spain could be explain with a value of $\omega_{h}$ close to 0.9 or higher, which is unrealistically large. The German high rental share could not be explained with preference parameters only. In light of these results, there should be other reasons, complementary to preferences, to fully explain these cross-country differences.

Tax incentives are also a crucial factor in the housing sector. The housing market is a target for economic policy. In particular, there are many fiscal exemptions and subsidies for investments and activities related to housing [see, for example, ECB (2003)]. Taxes and subsidies directly affect the decision taking of agents in housing matters. In particular, taxation affects the choice between housing investment and investment in other assets, the choice between new and secondhand housing, and the choice between purchase or renting a house. In Tables 3 and 4, we can also see a numerical summary of the results.

\begin{tabular}{|c|c|c|c|c|c|c|}
\hline & $\tau_{h}=0$ & \multicolumn{2}{|c|}{$\tau_{h}=\mathbf{0 . 1 0}$} & \multicolumn{2}{|c|}{$\tau_{h}=0.15$} & $\tau_{h}=$ \\
\hline Debt/GDP & 0.51 & \multicolumn{2}{|c|}{0.69} & \multicolumn{2}{|c|}{0.83} & 1.2 \\
\hline Rental/Purchase & 0.40 & \multicolumn{2}{|c|}{0.36} & \multicolumn{2}{|c|}{0.33} & 0.2 \\
\hline \multicolumn{7}{|c|}{ Table 4: Steady-state values for different $\tau_{z}$} \\
\hline & \multicolumn{2}{|r|}{$\tau_{z}=\mathbf{0}$} & \multicolumn{2}{|c|}{$\tau_{z}=0.15$} & \multicolumn{2}{|c|}{$\tau_{z}=0.25$} \\
\hline Debt/GDP & \multicolumn{2}{|r|}{0.69} & \multicolumn{2}{|c|}{0.62} & \multicolumn{2}{|c|}{0.56} \\
\hline \multicolumn{2}{|c|}{ Rental/Purchase } & 0.36 & 0.4 & & 0. & 45 \\
\hline
\end{tabular}

These tables show how the residential debt values and the proportion of rentals versus purchases change when a subsidy to home purchases is introduced. As would be expected, when the subsidy increases, the debt ratio also increases because agents borrow more to finance their housing. However, the rental proportion decreases because rentals are the substitute for home purchases, which increase with the subsidy. 
If, on the contrary, there is a subsidy for rentals, we can see the opposite effects. When rentals are encouraged, the residential debt-to-GDP ratio decreases and the relative proportion of rentals in the economy increases.

Again, this factor alone could not explain the polar cases in Europe. However, as can be seen, a combination of strong preferences for owner-occupied housing and favorable taxation towards owning can be the cause of the low rental share in a country such as Spain, or some Eastern European countries. Analogously, a combination of preferences for renting and favorable taxation towards renting could be behind the high rental share in a country such as Germany.

\section{Model Dynamics}

In this section, I present impulse responses to an increase in the interest rate corresponding to one standard deviation (0.29 percent). ${ }^{16}$ First, I display the benchmark case, corresponding to the US parameterization shown above. Then, I compare different situations in which alternative parameterizations imply high and low rental shares. ${ }^{17}$

\subsection{Benchmark}

Figure 1 shows impulse responses for the benchmark case, in which there is an equal preference for rented and owner-occupied housing in the borrowers' utility function and there are no subsidies.

This restrictive monetary policy action, shown in Figure 1, reduces as expected economic activity and inflation. Real housing prices move inversely with the interest rate, as does any asset price. On the other hand, the increase in housing financing cost makes borrowers reduce their housing stock with mortgages and substitute them for rented houses. Furthermore, this effect is reinforced first by an initial fall in housing prices, which reduces the value of owner-occupied housing as a collateral, and second by the fall in the rental price. The rental price falls because owners expect a rapid recovery in real housing prices. ${ }^{18}$ The fall in the rental price produces an increase in rented houses. Both borrowers and savers reduce their consumption. Savers, given the interest rate increase, smooth their consumption and intertemporally

\footnotetext{
${ }^{16}$ Iacoviello (2005) estimates a Taylor rule for the US and finds a value of 0.29 percent at a quarterly frequency. I use this value as an empirically plausible one.

${ }^{17}$ For simplicity, in the model, the government is assumed to pay lump-sum transfers to saver households, but not to borrower households. Results in the paper are not driven by this assumption. To check that, I have run the model assuming the extreme case where all transfers are given to borrowers, and found that the model dynamics are essentially unchanged.

${ }^{18}$ This effect can be observed rewriting equation (5) as $q_{z, t} A_{z}=q_{h, t}-\beta_{s} E_{t}\left(\frac{C_{s, t}}{C_{s, t+1}}\right) q_{h, t+1}$. Rental prices move directly with current house prices but inversely with expected future house prices.
} 

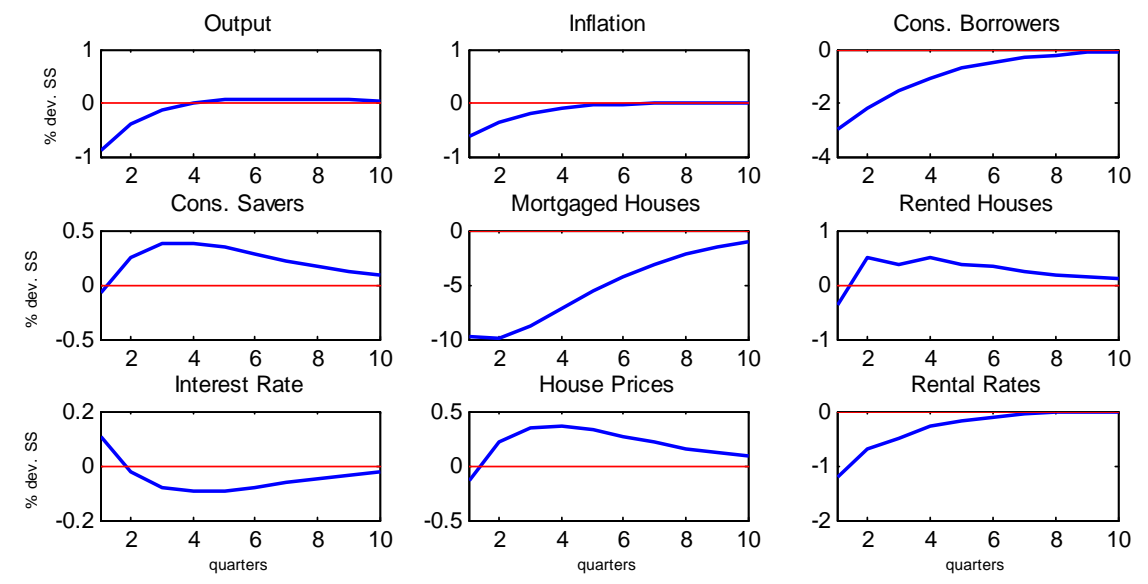

Figure 1: Impulse responses to a monetary policy shock. Benchmark

substitute, consuming less in the present to be able to consume in the future. Borrowers, however, suffer a negative effect on their consumption due to their collateral constraint: the fall in housing prices and in housing demand reduces the collateral value for mortgages and causes a larger fall in consumption. This decrease in consumption implies a reduction in economic activity and inflation.

Impulse responses coming from the theoretical model are in line with the empirical evidence. For instance, Iacoviello (2005) estimate a VAR for the US economy including housing variable. This study finds that house prices move inversely with the interest rate, because they are an asset price. Towbin and Weber (2015) extend the VAR to include variables related to rental markets. They perform a similar experiment considering a mortgage interest rate shock. They find that a decrease in the mortgage rate (which would be equivalent to an expansionary monetary policy shock), drives the house price up, the rent-to-price ratio down, and the vacancy rate up. That would be the mirror image of the theoretical experiment I run with my model.

However, the dynamics of the model may change with the parameters affecting housing tenure. Responses in the markets for mortgage or rented houses are going to be more or less sensitive to changes in monetary policy depending on preferences, institutions, and taxation, and this may be transmitted to the real economy. The following subsections display those cases.

\subsection{Preferences and the Efficiency of Institutions}

Figure 2 presents impulse responses to a monetary policy shock for the benchmark and two different parameterizations. The solid line corresponds to the US calibration. The marked line to a situation in which consumers have a high preference for owner-occupied housing $\left(\omega_{h}=0.8\right)$. The dashed line 

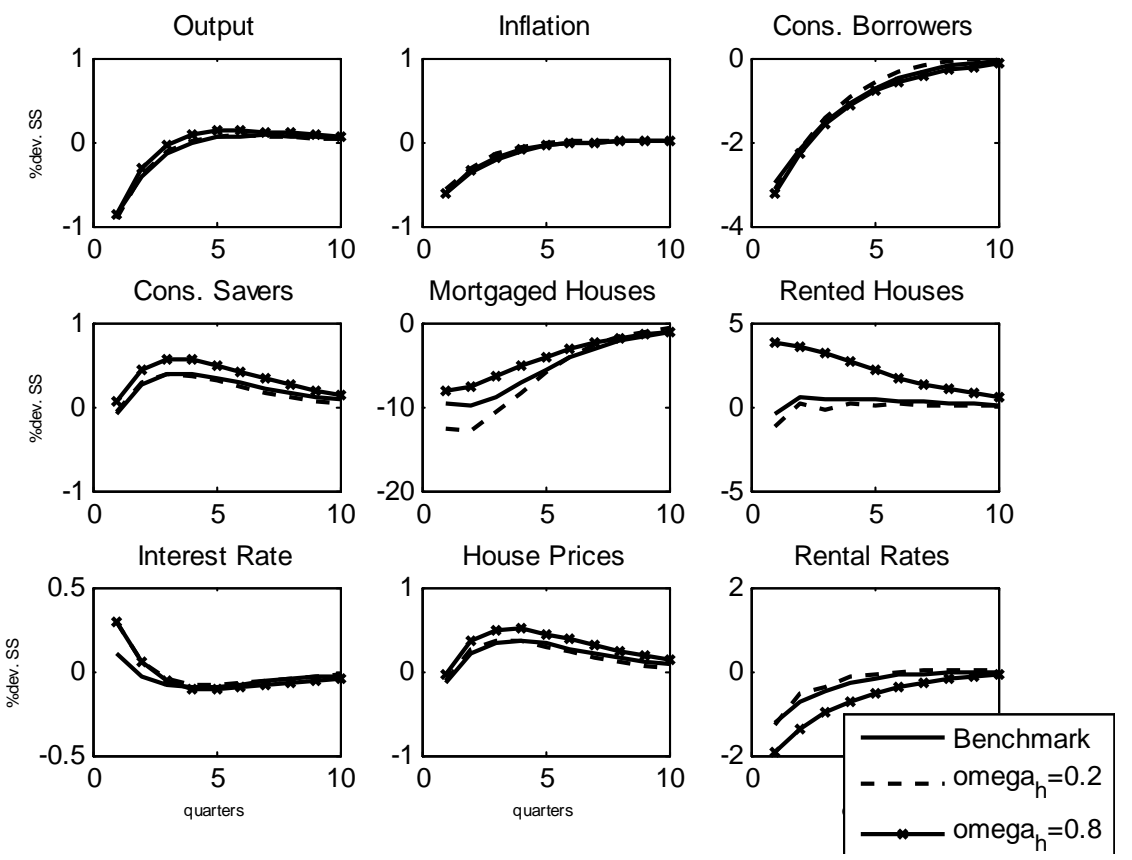

Figure 2: Impulse responses to a monetary policy shock. High versus low preference for owner-occupied housing and benchmark

represents consumers preferring rented houses more strongly $\left(\omega_{h}=0.2\right)$.

Given an increase in interest rates and the consequent fall in house prices, mortgaged houses fall in all cases. However, when the preference for owner-occupied housing is lower, mortgaged houses decrease more strongly because they have less value in terms of utility for consumers. This sharper decrease in mortgaged houses, in the case of low preference for owner-occupied housing, produces a stronger fall in the collateral held by borrowers. Then, in this case, borrowers' wealth decreases more, and by way of compensation, rented houses fall. In the case in which consumers have a preference for owner-occupied housing in the utility function, wealth does not decrease as much and, given the fall in rental rates, rented houses increase. When consumers' preference for rented houses is stronger, even though rental rates also fall, the decrease in wealth makes them cut rented houses for the level of consumption to not fall dramatically (notice that consumption has a stronger weight in the utility function than housing). As a result, given that borrowers readjust their rentals, at the aggregate level, there is no substantial difference between the two scenarios. Different preferences in housing tenure produce a redistribution between rented and purchased houses but the aggregate economy is only slightly affected.

However, even if preferences and institutional efficiency generate differences in housing markets, the implications for the overall economy are not so large. We will see that taxation is able to produce more 

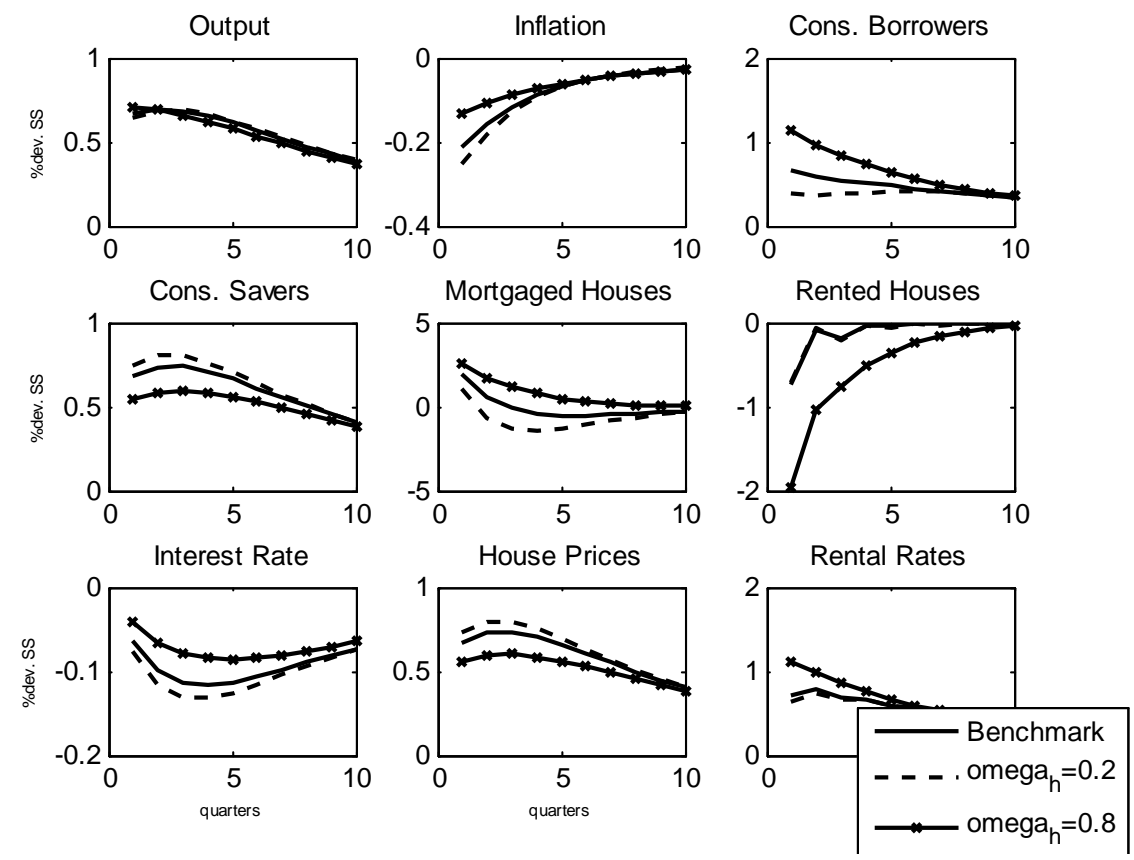

Figure 3: Impulse responses to a technology shock. High versus low preference for owner-occupied housing and benchmark

remarkable differences in output, inflation, and house prices.

For the sake of completeness, I repeat the experiment for a technology shock. Figure 3 shows that the technology sock, accompanied by a decrease in the interest rate, is expansionary for the owner-occupied housing market, especially when there is a strong preference for this types of houses, as expected. Therefore, consumers substitute rented houses by mortgaged houses and this effect is stronger the larger the preference parameter is.

\subsection{Tax incentives}

Figure 4 displays impulse responses to a monetary policy shock given different fiscal treatment for housing. In particular, the solid line represents the benchmark. The dashed line is case in which owner-occupied housing is subsidized to $25 \%$. The marked line is the case in which rented houses are subsidized.

When a subsidy to owner-occupied housing is introduced, this affects both borrowers and savers. Real housing prices are lower, in effective terms, for both groups. When there is a positive monetary policy shock, borrowers substitute away from rented houses for mortgaged houses. This strong increase in mortgaged houses greatly increases debt repayments and borrowers have to reduce their consumption 

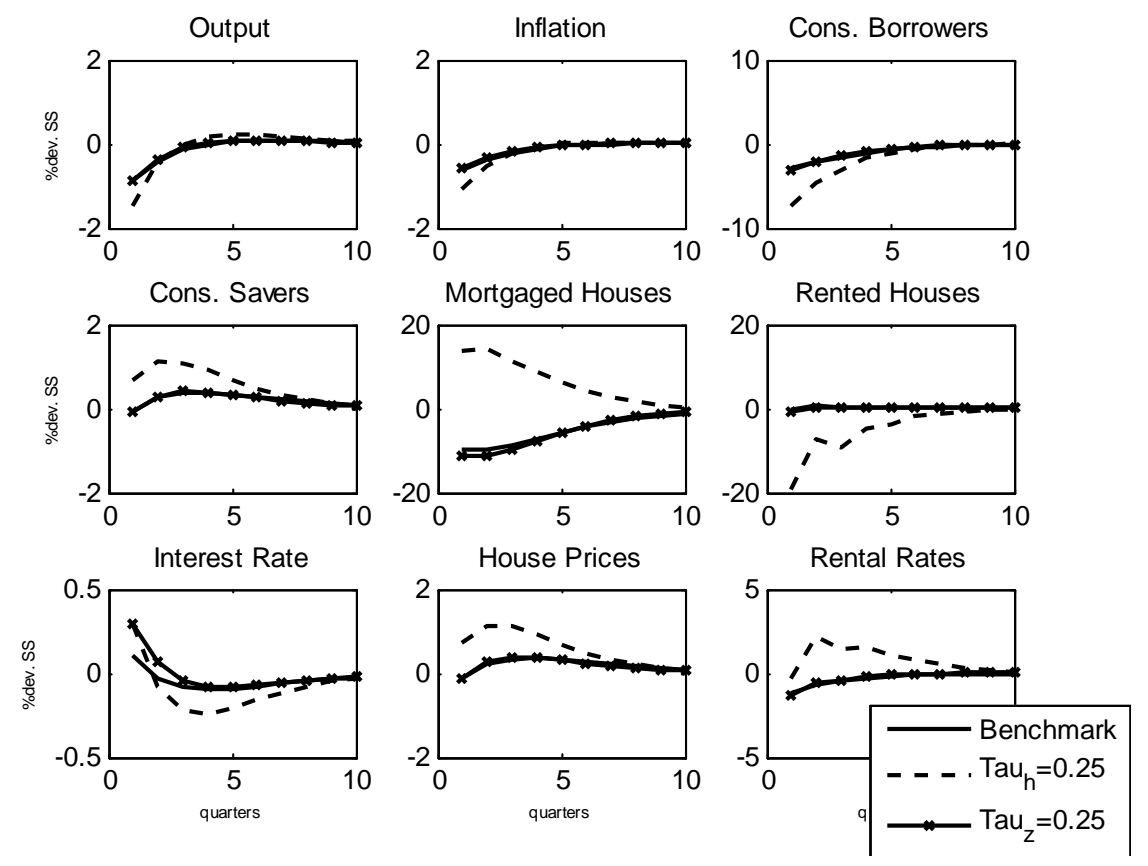

Figure 4: Impulse responses to a monetary policy shock. Favorable fiscal treatment to owner-occupied housing versus rentals and benchmark

to meet their debt obligations. Following this effect, output and inflation fall strongly. The interest rate reacts to the fall in inflation and starts to decrease. The fall in the interest rate makes savers increase consumption following their Euler equation. Saving decreases as a result and, for credit markets to clear, borrowing also decreases. This effect makes consumption by borrowers decrease even further.

When instead rentals are subsidized, the increase in the interest rate makes borrowers substitute away in the opposite direction, that is, buy more rented houses. The fall in house prices, the increase in the interest rate, and the favorable tax treatment for rented houses decrease mortgaged houses. This produces a fall in the value of the collateral for borrowers, which in turn decreases consumption by borrowers. The increase in interest rates reduces savers' consumption. These two effects together reduce economic activity and inflation.

Results show that different tax treatments have an effect on how monetary policy transmits to the real economy. In this case, it is not a mere redistribution between rented and purchased homes but it also affects consumption, output, and inflation differently depending on the subsidy that is applied.

Figure 5 shows impulse responses for a technology shock for the same three cases. Here, we see that the subsidy on houses produces an income effect on borrowers and this causes the shock to be more expansionary in this case. This make the interest rate not to react as much in this case. 

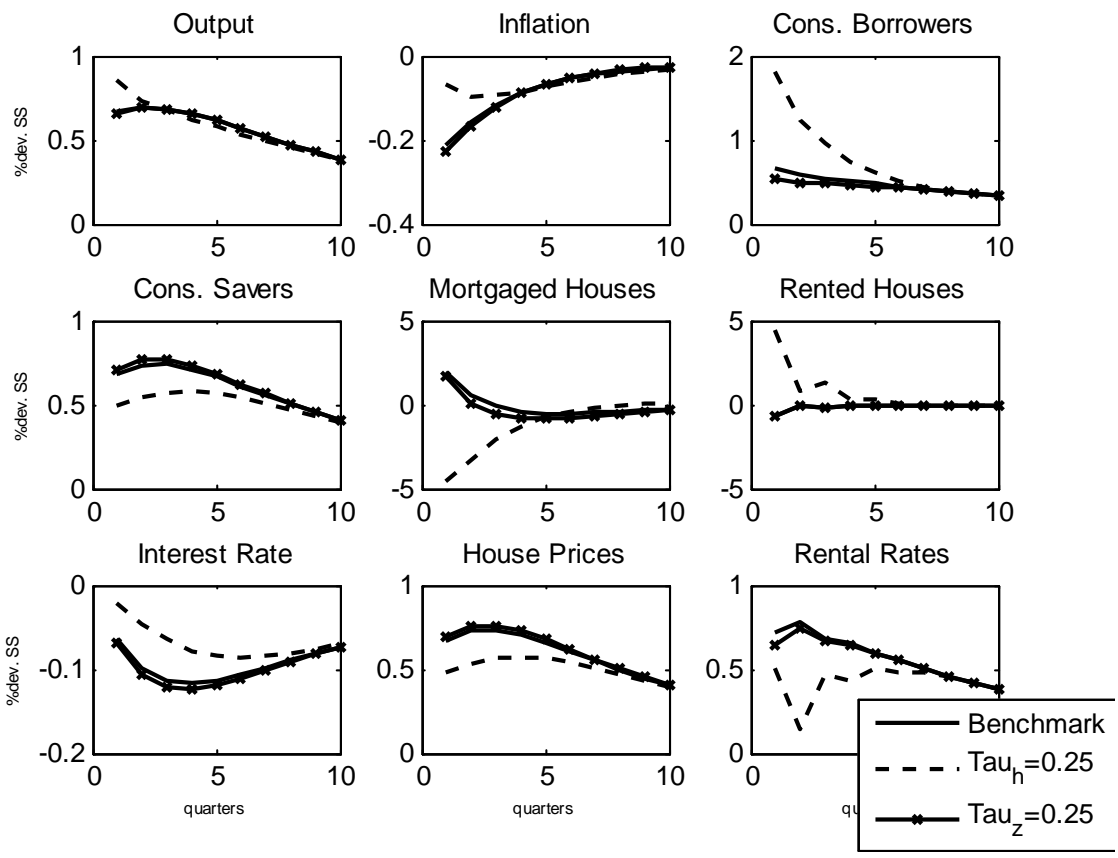

Figure 5: Impulse responses to a technology shock. Favorable fiscal treatment to owner-occupied housing versus rentals and benchmark

\section{$5 \quad$ Policy Frontiers}

To examine the implications of these structural and fiscal factors in housing markets for the efficiency of monetary policy, I compute policy frontiers. These frontiers, also known as Taylor curves, display the trade-off that central banks face when trying to stabilize output and inflation. ${ }^{19}$ A curve that is closer to the origin represents a situation in which monetary policy is more efficient in the sense of stabilizing inflation and output at the same time. ${ }^{20}$

Figure 6 displays the Taylor curve for two different values of the parameter that dictates the preference for owner-occupied versus rented houses. The solid line represents a situation in which owner-occupied houses are preferred to rented ones. The dashed line represents the opposite case. These two cases correspond to the two situations presented in the previous section, with impulse responses. The point corresponding to the benchmark calibration is also presented (red triangle). We can see from the figure that monetary policy is more efficient when consumers prefer rented houses. Given the same change in the interest rate, when borrowers prefer rented houses, changes in house prices do not affect the real

\footnotetext{
${ }^{19}$ Here, it is assumed that the policy maker aims at minimizing these variances but without making any assumptions about the loss function.

${ }^{20} \mathrm{I}$ compute the Taylor curves as the minimum values of inflation and output variance for different values of the policy rule parameters. To generate the trade-off, I consider cost-push shocks with a 0.02 standard error, corresponding to the estimates in Iacoviello and Neri (2010). Inflation is measured on a quarterly basis.
} 


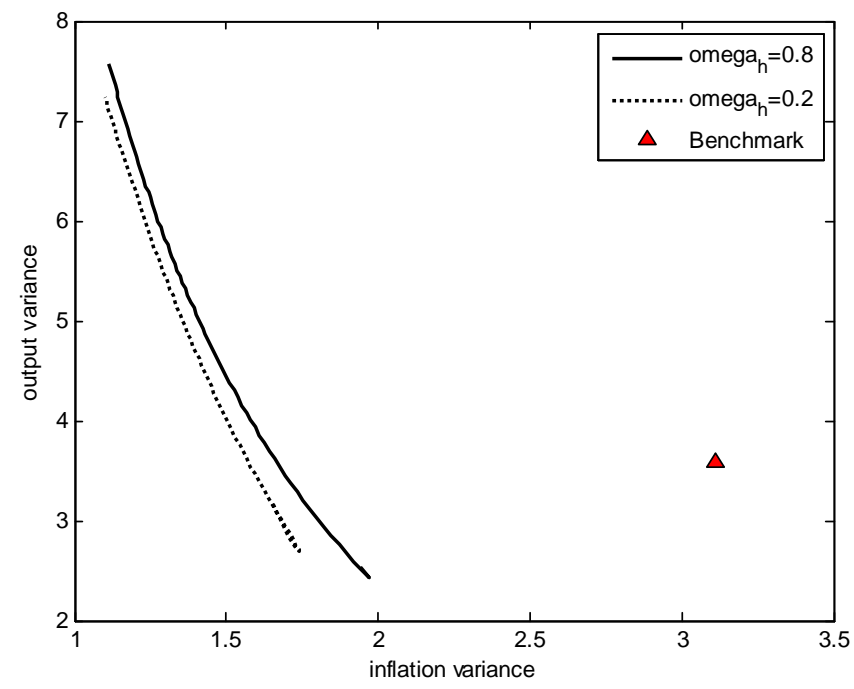

Figure 6: Policy frontier. High versus low preference for owner-occupied housing and actual point (benchmark)

economy as much, providing a more stable scenario. Collateral effects may exacerbate the trade-off between output and inflation variability, so that an environment in which these effects are softened by preferences may deliver more economic stability.

As for the dynamics of the model, the efficiency of the institutions and the preference factor deliver similar results. In both cases, the scenario in which the rental market share is larger provides a more stable situation. A similar argument applies here. In a situation in which it is easier to derive housing services from rentals, borrowers substitute mortgaged housing by rentals. Therefore, changes in house prices coming from monetary policy do not produce destabilizing collateral effects.

Figure 7 displays the case in which fiscal treatment favours either owning or renting. The benchmark calibration point is also displayed. In one situation, subsidies are given to home purchasers whereas in the other subsidies benefit rentals. We see that, in this case, monetary policy is more efficient when home purchase is subsidized. On the one hand, subsidizing rentals makes the economy less dependent on housing price movements, as in the previous case. However, subsidizing home purchases means that changes in house prices are effectively smaller because the subsidy represents a reduction in the real housing price, for both types of consumers. Then, a change in real house prices coming from a change in monetary policy affects the economy less and therefore increases stability. 


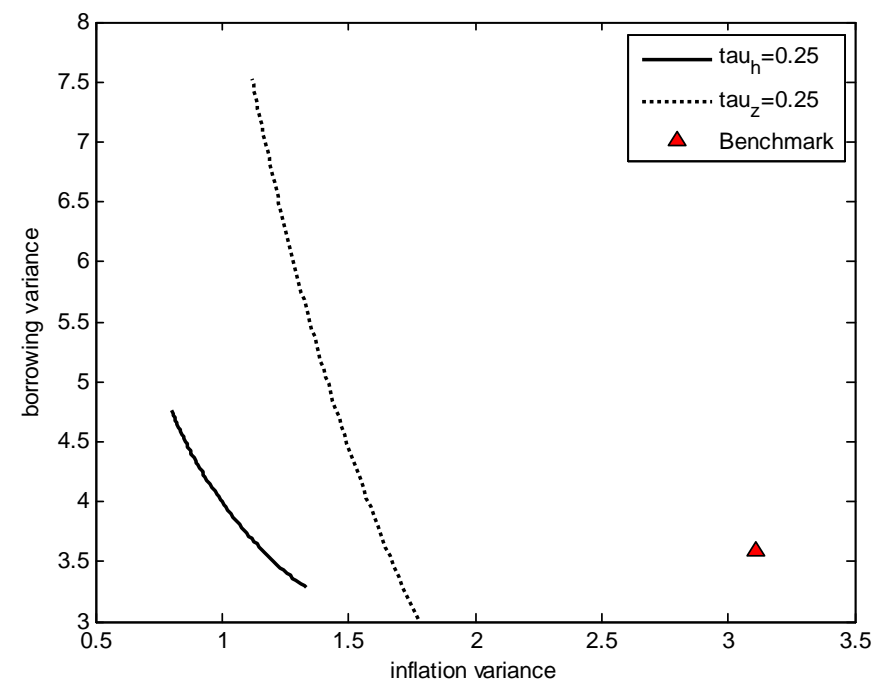

Figure 7: Policy frontier. Favorable fiscal treatment of owner-occupied housing versus rentals and actual point (benchmark)

\section{Optimal Monetary Policy}

So far, we have seen that, for a given monetary policy, a change in the interest rate is transmitted differently depending on the structural parameters that affect rental and owner-occupied housing markets. Furthermore, the efficiency of monetary policy is also affected by these structural and fiscal factors. In this section, we study the optimality of monetary policy for each case. I restrict the analysis to simple, linear rules in which interest rates respond to output and inflation. In particular, for each situation, I search for the combination of reaction parameters in the Taylor rule (both for output and inflation) that maximizes total welfare.

As a measure of welfare, I solve the model using a second-order approximation to the structural equations for given policy and then evaluate welfare using this solution. As in Mendicino and Pescatori (2007), I take this latter approach to evaluate the welfare of the two types of agents separately. ${ }^{21}$ The welfare of the individual for savers and borrowers, respectively, follows:

$$
W_{s, t} \equiv E_{t} \sum_{m=0}^{\infty} \beta_{s}^{m}\left[\log C_{s, t+m}+j \log H_{s, t+m}-\frac{\left(N_{s, t+m}\right)^{\eta}}{\eta}\right],
$$

\footnotetext{
${ }^{21}$ I used the software Dynare to obtain a solution for the equilibrium implied by a given policy by solving a second-order approximation to the constraints, then evaluated welfare under the policy using this approximate solution, as in SchmittGrohe and Uribe (2004). See Monacelli (2006) for an example of the Ramsey approach in a model with heterogeneous consumers.
} 


$$
W_{b, t} \equiv E_{t} \sum_{m=0}^{\infty} \beta_{b}^{m}\left[\log C_{b, t+m}+j \log \widetilde{H}_{b, t+m}-\frac{\left(N_{b, t+m}\right)^{\eta}}{\eta}\right]
$$

Following Mendicino and Pescatori (2007), I define social welfare as a weighted sum of the welfare of individuals for the different types of households:

$$
W_{t}=\left(1-\beta_{s}\right) W_{s, t}+\left(1-\beta_{b}\right) W_{b, t} .
$$

Each agent's welfare is weighted by his/her discount factor, respectively, so that all groups receive the same level of utility from a constant consumption stream. ${ }^{22}$

Table 5 presents the values for the Taylor rule parameters that maximize welfare, as defined above.

\begin{tabular}{lcc}
\hline \hline \multicolumn{2}{c}{ Table 5: Optimal values for Taylor rule parameters } \\
\hline \hline & $\left(1+\phi_{\pi}^{*}\right)$ & $\phi_{y}^{*}$ \\
\hline \hline Low rental share $(\simeq 10 \%)$ & & \\
$\omega_{h}=0.8$ & 1.1 & 0.005 \\
$\tau_{h}=0.25$ & 1.11 & 0 \\
\hline \hline High rental share $(\simeq 30 \%)$ & \\
$\omega_{h}=0.2$ & 1.19 & 0 \\
$\tau_{z}=0.25$ & 1.19 & 0 \\
\hline \hline
\end{tabular}

We see that for cases in which the rental share is high, because the collateral effect is less strong, it is optimal to respond more aggressively against inflation but the output response is negligible. For the case in which $\omega_{h}=0.8$, corresponding to a low rental share, it is optimal to slightly increase the response of the interest rate to output. Because the collateral effects in this case are stronger, it is optimal to cut these effects by responding to output more strongly. The case in which $\tau_{h}=0.25$ is a special one because even though the rental share in this case is low, and this should increase the collateral effects, the economy's exposure to changes in house prices is softened by the subsidy, which in this case applies to both agents, making monetary policy more efficient. Therefore, monetary policy does not need to be as aggressive either for inflation or for output to stabilize the economy.

\footnotetext{
${ }^{22}$ In models with collateral constraints, it is difficult to construct analytically Woodford type loss and welfare functions, because of the presence of borrowers and savers. A solution that it is typically used in the literature is to use individual utility functions and numerically compute welfare, using some sort of aggregation.
} 


\section{Conclusions}

Rental markets present clear differences across countries in terms of size, efficiency, and dynamism. This heterogeneity responds to different factors: consumer preferences, fiscal treatment of housing purchase versus rental, the institutional framework, or the development of the financial market, among others. I propose a dynamic stochastic general equilibrium model that captures all these issues. It features a housing market, both rented and owner-occupied. Borrowers face credit constraints and use their purchased housing as collateral. I then use the model to study how these characteristics affect monetary policy.

This setting is able to reflect the basic points that determine the differences between the rental markets across countries. It also recovers a fundamental concept in housing markets, namely financial accelerator effects derived from collateral constraints. Therefore, it is a valid framework for comparative analysis of different economic policies to modify the relative weight of home purchases versus rentals.

The model generates impulse responses that are in line with economic theory and empirical evidence, in which an increase in the interest rate contracts the economy and decreases owner-occupied housing in favor of rentals. Within this theoretical framework, the preference or cultural factor that affects the proportion of rentals with respect to purchases is reflected by the parameter associated with the weight of home purchases in the utility function. The model generates a steady state in which the higher this parameter is, the more agents are indebted and the less they rent. The fiscal treatment of the housing market is reflected by a subsidy to home purchasers and a subsidy to rentals. The subsidy to purchasers decreases the proportion of rentals while debt increases. The subsidy to rentals has the opposite effect.

I present impulse responses to a monetary policy and a technology shock under the different structural settings. Simulations show that shocks are transmitted in a different way through the housing market depending on the relative size of rentals versus owner occupation. These structural and fiscal differences also have implications for the efficiency of monetary policy. Results show that when the relative size of the rental market is larger, monetary policy is more stabilizing than in the benchmark scenario. However, when the government subsidizes home purchasers, the link between monetary policy and house prices is weaker and this creates an even more stable scenario. An optimal monetary policy analysis suggests that when the relative size of the rental market is large, monetary policy should respond more aggressively to inflation and disregard output, because the financial accelerator effects are weaker in this case. 


\section{Appendix}

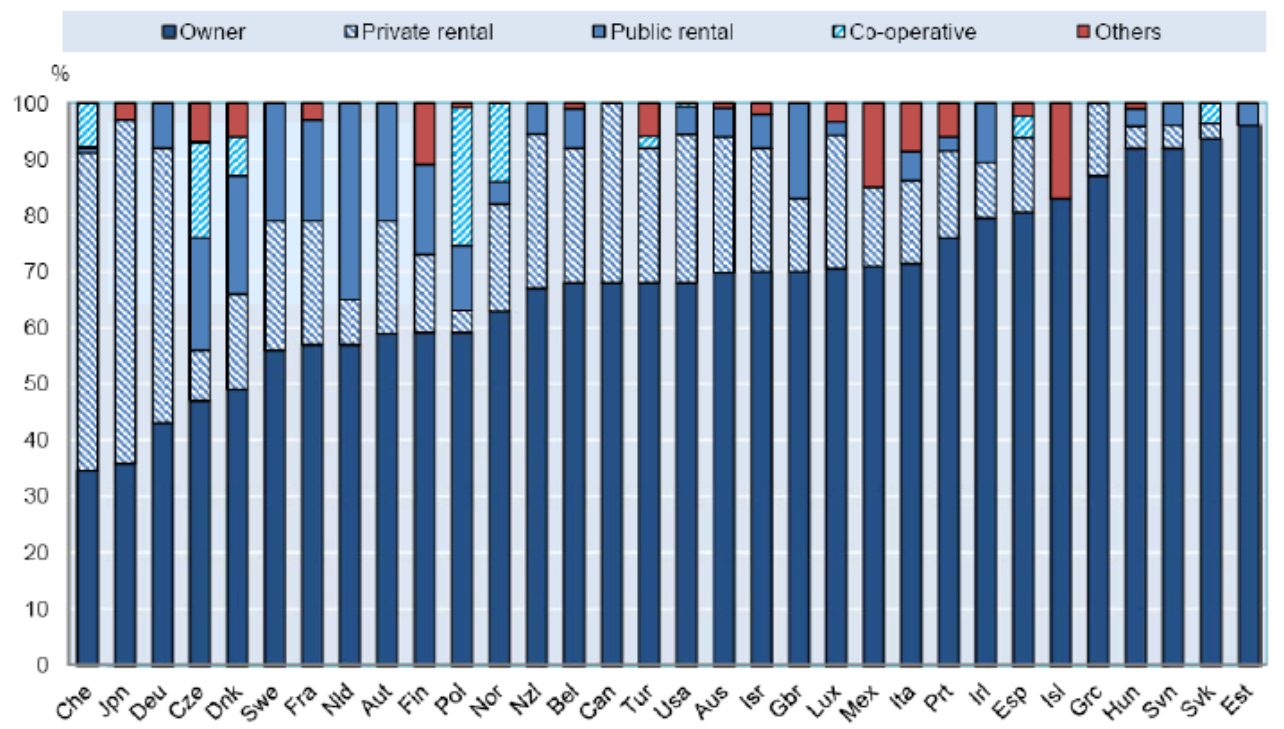

Figure A1: Tenure structure across countries. Percent of dwelling stock (2009). Source: OECD

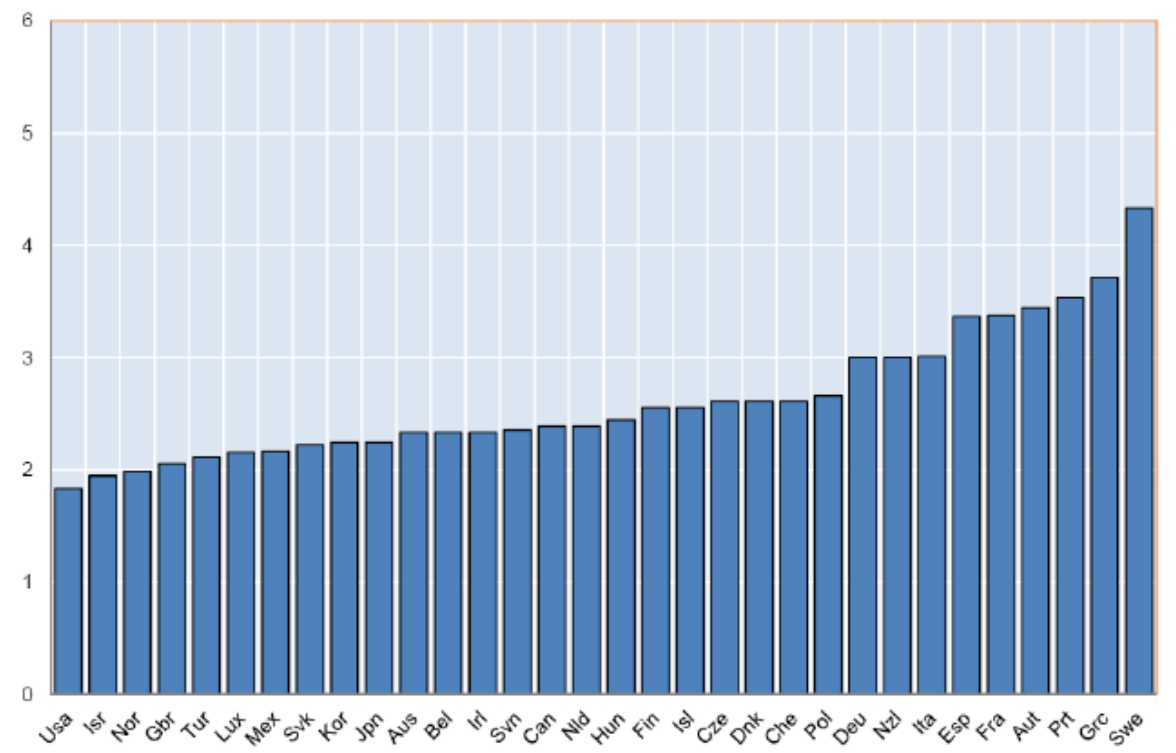

Figure A2: Tenant-landlord regulations in the private rental market (2009). Scale 0-6 increasing in protection for tenants. Source: OECD 


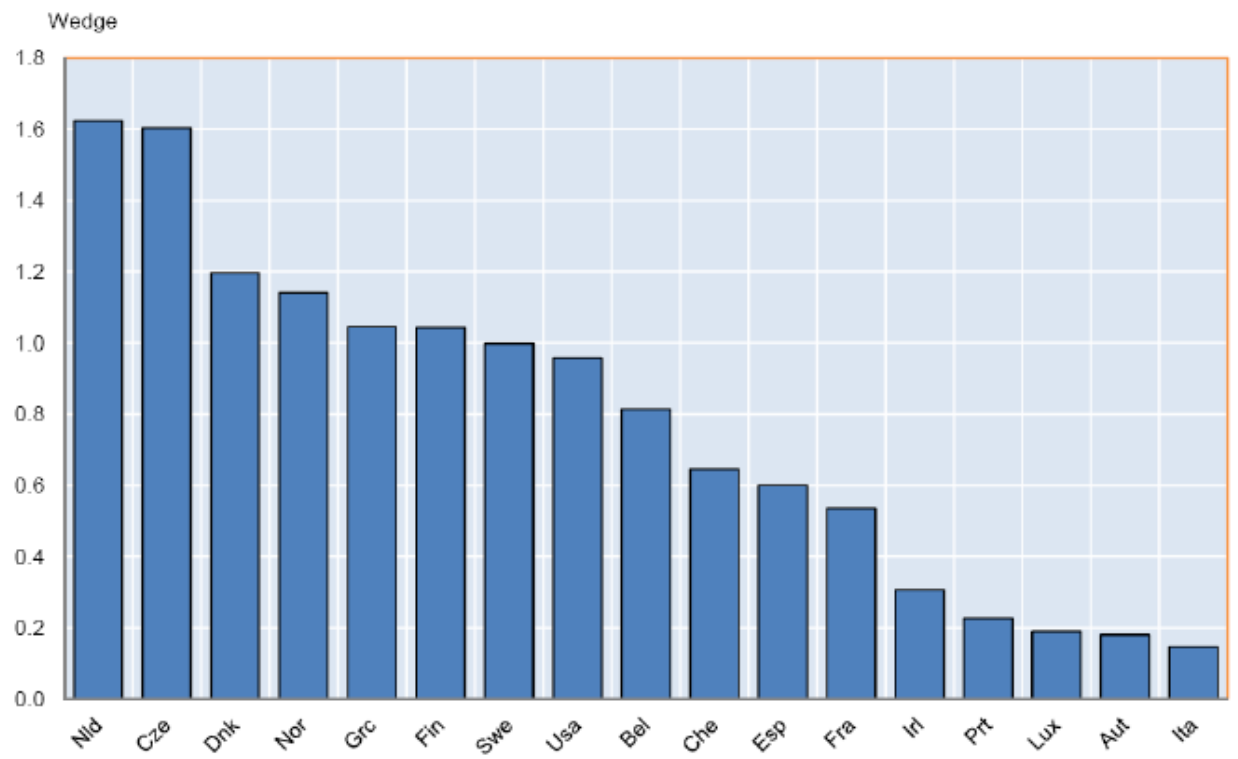

Figure A3: Tax relief on debt financing cost of home ownership (2009). Source: OECD

\begin{tabular}{lcccc}
\hline \hline Justice & is slow & is not affordable & does not enforce decisions & is a great obstacle \\
\hline \hline [OLE6] France & $47,0 \%$ & $16,3 \%$ & $2,1 \%$ & $4,1 \%$ \\
Germany & $20,6 \%$ & $18,6 \%$ & $4,2 \%$ & $8,0 \%$ \\
Italy & $62,4 \%$ & $43,8 \%$ & $8,9 \%$ & $16,3 \%$ \\
Spain & $41,2 \%$ & $13,5 \%$ & $4,2 \%$ & $12,2 \%$ \\
UK & $17,3 \%$ & $18,2 \%$ & $1,0 \%$ & $2,0 \%$ \\
US & $23,2 \%$ & $25,3 \%$ & $7,1 \%$ & $2,2 \%$ \\
\hline \hline
\end{tabular}

Table A1: Enforcement contracts indicators (World Business Environment). Source: Mora-Sanguinetti $(2011)$ 


\section{References}

[1] ALPANDA, S., S. ZUBAIRY (2016). "Housing and Tax Policy." Journal of Money, Credit and Banking, 48, 485-512.

[2] ANDREWS, D., A. CALDERA (2011). Drivers of Homeownership Rates in Selected OECD Countries. OECD Economics Department Working Paper, 849.

[3] BARSKY, R., C. HOUSE, and M. KIMBALL (2007). "Sticky-Price Models and Durable Goods." American Economic Review, 97 (3), 984-998.

[4] CAlvO, G. (1983). "Staggered Prices in a Utility-Maximizing Framework." Journal of Monetary Economics, 12 (3), 383-398.

[5] CASAS-ARCE, P., A. SAIZ (2010). "Owning versus Renting: Do Courts Matter?" The Journal of Law and Economics 53, 137-.165.

[6] CHAmberS, M. S., C. GARRIGA, and D. SCHLAGENHAUF (2009). "The Loan Structure and Housing Tenure Decisions in an Equilibrium Model of Mortgage Choice." Review of Economic Dynamics 12, 444-468

[7] CHAtterJeE, S., B. EYIGUNGOR (2014). A Quantitative Analysis of the US Housing and Mortgage Markets and the Foreclosure Crisis. Working Paper, Federal Reserve Bank of Philadelphia.

[8] CORBAE, D., E. QUINTIN (2015). "Leverage and the Foreclosure Crisis." Journal of Political Economy 123 (1), 1-65.

[9] DOMEIJ, D., M. FLODEN (2006). "The Labor-Supply Elasticity and Borrowing Constraints: Why Estimates Are Biased.” Review of Economic Dynamics, 9, 242-262.

[10] DYNAN, K., T. GAYER, and N. PLOTKIN (2013), An Evaluation of Federal and State Homebuyer Tax Incentives. Economic Studies at Brookings

[11] EARLEY, F. (2004). "What Explains the Differences in Homeownership Rates in Europe." Housing Finance International 19, 25-30.

[12] ECB (2003). Structural Factors in the EU Housing Markets. ECB Report. 
[13] IACOVIELLO, M. (2005). "House Prices, Borrowing Constraints and Monetary Policy in the Business Cycle." American Economic Review 95 (3), 739-764.

[14] JESKE, K., LIU, Z., (2013). "Should the Central Bank be concerned about Housing Prices?" Macroeconomic Dynamics, 17, 29-53.

[15] LAWRANCE, E. (1991). "Poverty and the Rate of Time Preference: Evidence from Panel Data." The Journal of Political Economy, 99 (1), 54-77.

[16] MENDICINO, C., A. PESCATORI (2007). Credit Frictions, Housing Prices and Optimal Monetary Policy Rules, mimeo

[17] MONACELLI, T. (2006). Optimal Monetary Policy with Collateralized Household Debt and Borrowing Constraints, in Conference Proceedings "Monetary Policy and Asset Prices" edited by J. Campbell.

[18] MORA-SANGUINETTI, J. S. (2011). Algunas Consideraciones sobre el Mercado del Alquiler en España. Boletín Económico Noviembre 2011. Banco de España.

[19] MORA-SANGUINETTI, J. S., M. RUBIO (2014). "Recent Reforms in Spanish Housing Markets: An Evaluation Using a DSGE Model.” Economic Modelling, 44 (S1), S42-S49.

[20] NAKAJIMA, M. (2010). Optimal Capital Income Taxation with Housing. Working Paper, Federal Reserve Bank of Philadelphia.

[21] ORTEGA, E., M. RUBIO, and C. THOMAS (2011). "House Purchase versus Rental in Spain." Moneda y Crédito 232, 109-144.

[22] POMEROY, S., M. GODBOUT (2011). Development of the Rental Housing Market in Latin America and the Caribbean. Inter-American Development Bank, IDB-Dp-173.

[23] SCHMITT-GROHE, S., M. URIBE (2004). "Solving Dynamic General Equilibrium Models Using a Second-Order Approximation to the Policy Function.” Journal of Economic Dynamics and Control, $28,755-775$.

[24] TOWBIN, P., WEBER, S (2015). Price Expectations and the U.S. Housing Boom, IMF Working Paper, WP/15/ 182 